\title{
Developments and prospects of freight railway transport in Northem Germany: A Delphi survey
}

\author{
Gabriela Ztz \\ CITY College, Business Administration and Economics Department, Intemational Faculty of the \\ University of Sheffield, 3 Leontos So fou, 546 26, Thessa loniki, G reece, gmereuta@gmx.de \\ Aristides Matopoulos* \\ *Correspond ing a uthor, Engineering Systems \& Mana gement, School of Engineering \& Applied \\ Science, Aston University, Aston Triangle, Bimingham B4 7ET, UK, Tel: +44 121204 3595, Fax:+44 121 \\ 204 5079, a.matopoulos@aston.ac.uk
}

\begin{abstract}
Despite the fact that Gemany has a well expanded traffic infrastructure, it confronts a strong growth in freight volumes and it is very likely that in the forthcoming years will not be able to reasonably cope with the increasing demand. The a im of this paper is to explore the developments of the transport sector, railways in partic ular, in North Gemany. More specific, the paper explores whether the railway network could contribute to improved traffic development in North Gemany and also whether or not the existing logistics practices are effective enough to cope with the traffic problems in the region. The research based on the Delphi technique, collected, analysed and summarized the opinions of a group of experts in the aforementioned issues. Results indicate that railways could represent the solution to the forecasted growing freight volumes in the next years. In spite of continuous efforts undertaken by the politics and the economy, the existing logistics and freight traffic concepts are not sufficient, financing is too scarce, while emerging issues like sustainability, environment protection and working conditions are taken into little consideration.
\end{abstract}

Keywords: log istic s, ra il tra nsport, susta ina bility, Delphi method, Germa ny

\section{Introduction}

With a potential market volume (total costs) of nearly 900 billion EUR in the 27 European Union the logistics sector is among the biggest economic sectors, (Progtrans, 2009), whilst Gemany, with a revenue of more than 200 billion Euro represents by far one of the most important European logistic s markets (CBRE, 2012). Total inland freight transport in the EU27 was estimated to be close to 2200000 million tonne-kilometres (tkm) in 2009 with a growing pace (Eurostat, 2011). It is therefore no surprise that in recent years a growing interest in transport policy initiatives has been observed particularly on railway transportation. The role policy plays in developing logistics opportunities and implementing advanced logistic s systems has been well documented in the literature. For example, Bergqvist (2008) challenged the collaboration and coordination between different actors, e.g. the dynamics between shippers, operators and polic y-makers.

Railway traffic in many European countries has increased for both passenger and freight during the last few years and this trend is expected to continue (Caimi et al., 2009). 
Nevertheless, the freight share of rail transport in Europe is more or less disc ouraging (Table 1). This is often attributed to the differences in rail infrastructure in EU countries in terms of track conditions, gauge, signalling system, type of current and facilities, but also to other issues such as: road dominance, role of govemments and politicians and customer orientation, market entry bamiers and willingness to consider railways as a reliable partner in freight traffic (Ghijsen et al., 2007; Bulc su, 2011; La isi, 2011).

Table 1: Forecasted evolution of modal split in European (EU 25) freight transport (2000-2020) (Source: CEC, 2006).

\begin{tabular}{|l|l|l|l|}
\hline Mode of Transport & $\mathbf{2 0 0 0}$ & $\mathbf{2 0 1 0}$ & $\mathbf{2 0 2 0}$ \\
\hline Road & $43 \%$ & $46 \%$ & $45 \%$ \\
\hline Rail & $11 \%$ & $9 \%$ & $8 \%$ \\
\hline Inland waterways & $4 \%$ & $3 \%$ & $3 \%$ \\
\hline Pipelines & $3 \%$ & $3 \%$ & $3 \%$ \\
\hline Sea & $39 \%$ & $39 \%$ & $41 \%$ \\
\hline
\end{tabular}

In this paper we explore the developments of the transport sector, railways in particular, in North Germany. More specific, the paper investigates the extent to which the railway network could contribute to improved traffic development in North Gemany and also whether or not the existing logistics practices a re effective enough to cope with the traffic problems in the region. The main contribution of this paper is that it brings together the views from a vaniety of transportation experts in Germany providing insights on a number of critical issues in developing a sustainable rail transport network. Following an analysis of the transport sector with reference to Northem Gemany the research methodology is presented a long with an analysis of the findings. The paper continues with final conclusions, the contribution of this research, recommendations for further research, as well as research limitations.

\section{Freight transport in Northem Gemany: and current state}

\subsection{A view on polic ies and infrastructure}

In Gemany, freight traffic and logistics concepts benefited from "ambitious planning approach and advanced practical experience" (Hesse, 2004), as logistics was an active field of policies and planning concepts. An example of such policies was the freight village concept. The development of freight villages started in 1965 with the first sea container which landed in North Germany, in the port of Bremen. Then in 1985/6 Bremen authorities established the first German freight village in Bremen and today, after more than 20 years, there are 31 freight villages in operation in the whole country, with 1,300 enterprises in freight villages and over 45,000 employees. Some of the advantages of freight villages include access to rail and intemodal teminal, faster and easier logistics services as well as auxiliary services, less congestion, better city logistics, and 
environmental protection; in one phrase, resources for logistic s compa nies of all sizes. The most important Freight Village Area in Gemany is located in Berlin region, as it represents the gateway to Eastem Europe (e.g. Conta iner Tra in Eastwind runs 3 times a week BerlinMosc ow/Kazakhstan). The Freight Village Berlin South (Grossbeeren), with 150 ha a rea, 55 established enterprises, approximately 3,700 employees and East (Freienbrink) (Wagener, 2008).

Globalization, European integration and liberalization of transport market (although questioned by some authors, see Slack and Vogt, 2007) were expected to increase the volume of freight transport, while the infrastructure capacity and "handling of consignments" seemed to remain limited (Hesse, 2006) with shippers demanding highquality transport and logistics servic es at competitive prices (Bolis and Maggi, 2003). In the Geman North Area the case of the Port of Hamburg is very interesting as the well-proven model might not be sufficient to secure its competitive position in the future (Hesse, 2006). Hamburg is one of the most signific ant railway hubs in North Gemany, for both passenger and goods. In the Port of Hamburg, the Hamburger Hafenbahn (Port Railway) is responsible for the infrastructure and operations. The port has excellent connections into the hinterland as is evident in the growing market share of cargo moved by rail and inland waterways camiers. The Hamburg Port Authority (HPA), a commercially oriented institution under public law, manages all duties related to the area of this port.

At the same time modemisation projects, like the "Y-railway route" (new fast railway line from Hannover in Hamburg and Bremen direction that should be put at disposal in 1015 years) are implemented. Furthemore, the German Federal Ministry of Transport, Building and Urban Affairs (BMBVS, 2008) presented in March 2008 a draft of a Master Plan for Freight Transport and Logistics, which focused on the complex infrastructure and networking, initially conta ining 35 concrete measures that should enhance efficiency and make optimum use of the existing capacity in the German transport. This was followed by an official transport policy document which emphasized on five points (ranked below according to their importance for the transport sector):

1. Construction and development of traffic infrastructure;

2. Effic ient usa ge of the existing transportation routes;

3. Avoidance of unnecessary means of transport;

4. Better working conditions and good training programmes for the employees in the freight traffic sector;

5. Increase of life quality through environment and climate protection.

The Master Plan was oriented towards a more sustainable traffic policy, targeting on the optimal usage of transport routes, on traffic avoidance and mobility assurance, on environmental and susta inable traffic, lower and sa fety transport and good collaboration and training of personnel in the transport sector. Surprisingly, in the Master Plan seaports 
hinterland traffic was not considered. Seaport hinterland traffic is very important partic ula rly for railways.

Almost $20 \%$ of the total goods volume developed in the Geman ports are transported by rail. The increase of container traffic (in the last 10 years by more than 4 times) forecasted a strong growth in rail freight, namely in trains to and from the seaports; thus, additional network capacity and improved utilization of the existing network were required. Therefore, master plan projects for the rail infrastructure were developed by the National Railway Company (Deutsche Bahn AG), seaports authorities, major private railway operators and policy officials in order to improve the transport links between German ports and their hinterlands. Only by tighten collaboration between ports, DB AG, railway organisations and politicians the future hinterlands traffic could be mastered. Within the hinterlands traffic master plan project were the five largest Geman ports and their master plans represented the basis for the configuration of an efficient hinterland connection to the rail. Cargo and freight handling in the ports of Hamburg, Bremen/Bremerhaven, Wilhelmshaven, Lübeck and Duisburg are expected in the forthcoming years (until 2015) to increase up to $100 \%$.

\subsection{Recent developments and curentstate}

Coming back to the railways in Gemany, examples of rail line rehabilitation were provided by the Geman organization "Allianz pro Schiene". After the modemisation of the infrastructure and of the rolling stock, these rail lines were put into service again and contributed to the traffic fluidization and diminution of pollution. As a consequence, the market growth of the freight railway transport in Gemany, expressed in tonkm had constantly increased from $15.75 \%$ in 2002 to $17.1 \%$ in 2006 compared to $15.8 \%$, the a verage of $25 \mathrm{EU}$ states. In terms of goods traffic, in Germany, a pproximately $9 \%$ of goods a re transported by rail (CBRE, 2012).

Recent data have revealed that in spite of the economic crisis, the field of rail freight traffic has been further developed. For example, according to the 2009 Sustainability Report Association of German Transport Undertakings (VDV) 77.000 fully loaded trucks were transported by rail instead of road, with signific antly lower $\mathrm{CO}_{2}$ emissions (only a $1 / 3$ for the same operation). At the same time, freight transport companies transported more than 650 million tonnes in one year (public operations and non-public operations); while for the same period transport services within public rail freight transport grew to a p proxima tely 116 billion tonkms (VDV 2010a; VDV 2010b; VDV 2010c).

Much of the development of the rail transport sector was due to the private railway operators. Not only the passengers sector but also the cargo sector within DB has enc ountered numerous competitors. All together in Gemany, currently there are about 240 railway operators, which are intemationally active and involved in cross-border transactions. In particular, the market share of transport operators (for both passenger 
local and container traffic) that does not belong to DB has enomously increased. After an increase of $14.3 \%$ in 2010, the volume sold in 2011 rose once again, by approximately 8.5\% (DB Konzem, 2012). Moreover, the very dynamic development in the German freight transport (rail, road, inland wa terway) in 2010 continued a lso in 2011 and 2012, partic ula rly favorable for rail freight transport in 2011, with an increase in demand of nearly $9 \%$, according to the DB Report on the Geman Freight Traffic.

The existence of highly dynamic and successful small and medium-sized enterprises (SMEs) characterizes the Geman economy. There are about 3.3 million SMEs and this sector is attractive because of their technological edge and specialist knowledge. Regarding the national railway company Deutsche Bahn, which a imed to create regional units that would operate in the market in the same way as the SMEs, four regional organizational units were established (DB Konzem, 2012). These units were responsible for provision of infrastructure interlinked with rail transport operations, running regional services, partly on DB owned tracks. They proved to be real successful due to the quality of service, permanent innovation and satiffied employees.

The SME railway freight operators have ma inly occupied the niche market, for instance local traffic services in the mountainous Federal Land of Bavaria, Sachsen or Baden Württemberg. As for the passenger long-distance traffic, there is little competition to DB. On the contrary, the freight traffic (e.g. The Railway Port Duisburg or BASF operates a big railway industry, such as the Altona-Kaltenkirchener Railways Operator or the Mittelweserbahn Operator). These non-federally owned Railways Operators cover the demand in servic es like tank car and cartransportation, as well as ore bulk ca rier, coal or gravel freight. DB Netz, as a subsidiary of Deutsche Bahn AG, is the owner and administrator of DB Infrastructure, such as rail, energy provision, railway stations, etc. DB Netz is in no case the only rail infrastructure Operator in Germany. Industry Companies, Ports, Federal Lands and Municipalities altogether have at disposal over $30 \%$ of the Geman Infrastructure compared to DB Netz. DB Netz AG is according to the law obliged to give non-discriminatory access to its infrastructure and is fully responsible for the efficiency of the traffic on rail, as long as the safety standards of UIC are met (European Ra ilway Review, 2012).

With reference to sustainability, the Geman transport industry recognizes the severity of transport-related problems such as neglected road ma intenance and congestion (Link, 2008). In addition, the Geman National Railways Company, DB -Konzem (DB Konzem, 2008; DB Konzem, 2010a; DB Konzem 2010b), has already done a lot through the implementation of energy saving and climate protection programs. At the same time, the National Company analyses and consolidates its information about the problems caused by transport, in particular congestion and road deterioration as urgent ones through permanent press releases, revised web sites (see Deutsche Bahn and DB Schenker offic ial sites). 


\section{Research methodology}

The Delphi technique as a research methodology has been often employed in transport related studies, in order to identify core issues and trends in this field and to increase expertise interest in this emerging subject area. For example, the report on European Logistical and Supply Chain trends conducted between 1999 and 2005 by Mc Kinnon and Forster (2000), or Lummus et al. (2005) work on the characteristic s of flexible supply chain or even the work by Seuning and Müller (2007) which addressed core issues in sustainable Supply Chain Management. The Delphi methodology was therefore considered more appropriate for meeting the objectives and the context of this research.

\subsection{Selecting the experts}

According to Manoliadis et al. (2006) issues like definition of experts and their selection, number of rounds and questionnaire structure in each study round a re vital for the success of the research. Lee and King (2008) underlined the fact that Delphi techniques avoid face-to face interaction between panellists and demand expert opinions and judgements "inexpensively". Panel members cannot see and dominate others, removing pressure this way, and therefore opinion and consensus in the panel is generated a nonymously. At the same time, Delphi method allows an interaction between specia lists without meeting or knowing each other.

According to many authors, the success of a Delphi study lies upon the combined expertise of the participants who built up the expert panel. Thus, Powell (2003) argued that it was important for the panel members to be willing and able to make valid contribution, Chan et al. (2001) said that experts should have extensive working experience in that respective field, to be currently, recently or directly involved in the management, while Mitchell (1991) stressed the signific ant involvement in the industry of the experts, both in the past and in the present.

In this research, respondents were not randomly selected, but for a clear purpose in order to share their knowledge and experience to the freight traffic problem in Northem Gemany. In specific, selection of panel members was based on participants' long experience in transportation field and logistics, their specialized skills and partially, academic degree. Also, people from the political side were included in the panel. Once the sample was identified, the participants were informed about the nature of the study, its goals and objectives and their expected contribution. In total, 17 experts were contacted. The composition of the Delphi panel is presented below, in Table 3.

Table 3: Experts' panel

\begin{tabular}{|c|l|l|c|c|c|}
\hline Company & \multicolumn{1}{|c|}{$\begin{array}{c}\text { Type of Company/ } \\
\text { Industry }\end{array}$} & $\begin{array}{c}\text { Position held by the } \\
\text { panelist within the } \\
\text { Company }\end{array}$ & $\begin{array}{c}\text { Training/ } \\
\text { Academic } \\
\text { degree }\end{array}$ & $\begin{array}{c}\text { Length of } \\
\text { experience } \\
\text { (in years) }\end{array}$ & $\begin{array}{c}\text { Company's } \\
\text { location }\end{array}$ \\
\hline Deutsche & -National Railway & -Project Manager; & - Engineer & -25 & -Frankfurt \\
\hline
\end{tabular}




\begin{tabular}{|c|c|c|c|c|c|}
\hline Bahn Netz AG & $\begin{array}{l}\text {-Passenger \& freight traffic } \\
\text {-Rail Infrastructure }\end{array}$ & $\begin{array}{c}\text {-Manager } \\
\text { Intemational } \\
\text { Partnerships }\end{array}$ & - Engineer & -25 & $\begin{array}{l}\text { am Main } \\
\text {-Duisburg } \\
\text {-Berlin }\end{array}$ \\
\hline Railion AG & $\begin{array}{l}\text {-German Railway Cargo } \\
\text { Camier } \\
\text {-Deutsche Bahn subsidiary }\end{array}$ & Production Manager & Engineer & 20 & $\begin{array}{c}\text { Mainz/South } \\
\text { West } \\
\text { Germany }\end{array}$ \\
\hline $\begin{array}{l}\text { Hemann } \\
\text { Friedrich } \\
\text { Wiebe GmbH }\end{array}$ & $\begin{array}{l}\text {-Railway Track } \\
\text { Construction } \\
\text {-Rail Infra structure; } \\
\text {-Track Construction } \\
\text { Machines; }\end{array}$ & $\begin{array}{l}\text {-Vice-President; } \\
\text {-Financial Manager } \\
\text {-Logistics Manager }\end{array}$ & $\begin{array}{l}\text { - Engineer } \\
\text {-Economist } \\
\text { - Traffic } \\
\text { Supervision } \\
\text { Specialist }\end{array}$ & $\begin{array}{l}-35 \\
-15 \\
-10\end{array}$ & $\begin{array}{l}\text { Achim/North } \\
\text { Germany }\end{array}$ \\
\hline $\begin{array}{l}\text { Verband } \\
\text { Deutscher } \\
\text { Esenbahn } \\
\text { Ingenieure } \\
\text { e.V. (VDE } \\
\text { e.V.) }\end{array}$ & $\begin{array}{l}\text {-Association of Railway } \\
\text { Specialized Engineers for } \\
\text { Freight Traffic, Signaling, } \\
\text { Track Construction, } \\
\text { Power Lines; } \\
\text {-Facilitates and supports } \\
\text { ther technical, } \\
\text { economical and } \\
\text { scientific development } \\
\text { of the transport sector }\end{array}$ & President & $\begin{array}{l}\text {-Prof. Dr. } \\
\text { Engineer }\end{array}$ & 40 & $\begin{array}{l}\text { Frankfurt } \\
\text { am Main }\end{array}$ \\
\hline $\begin{array}{c}\text { Sozial } \\
\text { Demokratisc he } \\
\text { Partei } \\
\text { Bundestags } \\
\text { Fraktion - } \\
\text { Traffic } \\
\text { Department } \\
\end{array}$ & $\begin{array}{l}\text { Leader of the } \\
\text { Parlia mentary Social } \\
\text { Democratic Party - } \\
\text { Traffic Department }\end{array}$ & $\begin{array}{c}\text {-Congressman; } \\
\text { Vice-President of AG } \\
\text { Traffic, Construc tion } \\
\text { a nd City } \\
\text { Development }\end{array}$ & Engineer & 30 & Berlin \\
\hline $\begin{array}{l}\text { University of } \\
\text { Hannover- } \\
\text { Institute of } \\
\text { Transport, } \\
\text { Railway } \\
\text { Construction } \\
\text { and Operation }\end{array}$ & $\begin{array}{l}\text { Main scope of the } \\
\text { Institute: } \\
\text {-Transportation } \\
\text { supporting and } \\
\text { movement of goods by } \\
\text { railroad }\end{array}$ & $\begin{array}{l}\text { Head of the Railways } \\
\text { Construction } \\
\text { Department }\end{array}$ & $\begin{array}{l}\text { Prof. Dr. } \\
\text { Engineer }\end{array}$ & 40 & Hannover \\
\hline $\begin{array}{l}\text { Technical } \\
\text { University of } \\
\text { Munich (TUM) }\end{array}$ & -School of Education & $\begin{array}{l}\text { Head of Traffic } \\
\text { Department }\end{array}$ & Dr. Engineer & 15 & Munich \\
\hline $\begin{array}{l}\text { UNIFE-The } \\
\text { Association } \\
\text { of the } \\
\text { European } \\
\text { Rail Industry }\end{array}$ & $\begin{array}{l}\text { Main scope: } \\
\text {-to develop a proper } \\
\text { environment for UNIFE } \\
\text { members for providing } \\
\text { competitive railways } \\
\text { systems for increasing rail } \\
\text { traffic; } \\
\text {-to promote rail market } \\
\text { growth for sustainable } \\
\text { mobility }\end{array}$ & General Director & Engineer & 15 & $\begin{array}{l}\text { Brussels/ } \\
\text { Belgium }\end{array}$ \\
\hline $\begin{array}{c}\text { HIG } \\
\text { Ingenieurbüro } \\
\text { für Bauwesen } \\
\text { GmbH } \\
\end{array}$ & $\begin{array}{l}\text {-Civil Engineering; } \\
\text {-Construction Planning } \\
\text { and controlling; } \\
\text {-Project Managing; }\end{array}$ & General Manager & Engineer & 25 & $\begin{array}{l}\text { Schwerin/ } \\
\text { North East } \\
\text { Germany }\end{array}$ \\
\hline $\begin{array}{l}\text { Verband der } \\
\text { Bahnindustrie } \\
\text { in } \\
\text { Deutschland } \\
\text { (VDB e.V.) }\end{array}$ & $\begin{array}{l}\text {-Association of Railways } \\
\text { Suppliers Companies, } \\
\text { which deals with: } \\
\text { Rail technology; } \\
\text { Transport Policy; Control } \\
\text { and safety tec hnologies; } \\
\text { Infrastructure }\end{array}$ & Project Manager & Engineer & 30 & Berlin \\
\hline $\begin{array}{l}\text { Mittelweserb } \\
\text { ahn GmbH } \\
\text { (MWB) }\end{array}$ & $\begin{array}{l}\text {-Railroad Transportation } \\
\text { and Logistic S; } \\
\text {-Shunting } \\
\text { Tra ffic/Operations }\end{array}$ & Technical Manager & $\begin{array}{l}\text { Special } \\
\text { Tra ining in } \\
\text { Logistic S } \\
\text { and Traffic }\end{array}$ & 25 & $\begin{array}{c}\text { Bruchhausen- } \\
\text { Vilsen/ } \\
\text { North } \\
\text { Germany } \\
\end{array}$ \\
\hline
\end{tabular}




\begin{tabular}{|c|c|c|c|c|c|}
\hline & & & Control & & \\
\hline $\begin{array}{l}\text { Industrial } \\
\text { and } \\
\text { Commercial } \\
\text { Chamber } \\
\text { Stade for } \\
\text { Ebe-Weser } \\
\text { Region } \\
\end{array}$ & $\begin{array}{l}\text {-Insurance Intermediary } \\
\text {-Provision of services; } \\
\text {-Trade; } \\
\text {-Transportation/ } \\
\text { Infrastructure }\end{array}$ & Vice-President & Engineer & 20 & $\begin{array}{l}\text { North } \\
\text { Gemany } \\
\text { (between } \\
\text { Bremen } \\
\text { and } \\
\text { Hamburg) }\end{array}$ \\
\hline $\begin{array}{l}\text { European } \\
\text { Rail } \\
\text { Research } \\
\text { Network of } \\
\text { Excellence } \\
\text { (EURNEX } \\
\text { Association) }\end{array}$ & $\begin{array}{l}-47 \text { sc ientific institutes in } \\
\text { tra nsport a nd mobility } \\
\text { sector all over Europe; }\end{array}$ & Secretary General & Engineer & 15 & Berlin \\
\hline $\begin{array}{l}\text { Ecchholz Rail } \\
\text { GmbH } \\
\text { (EURAIL-ING) }\end{array}$ & $\begin{array}{l}- \text {-Railways } \\
\text {-Track construction \& } \\
\text { Machines } \\
\text {-Construction Engineering } \\
\text {-Catena ries Systems } \\
\text {-Weld ing Technology }\end{array}$ & Technical Manager & Engineer & 20 & Berlin \\
\hline
\end{tabular}

\subsection{The research tool}

Several studies identified that most changes in Delphi response occurred in the first two rounds and the forecast error decreased over successive iterations, "but the decrease between round 1 and 3 was only 10\%" (Mitchell, 1991). Therefore, in this research only two rounds were used due to time constrains. Typically, first round questionna ire is unstructured and open to any responses participants are willing to give; though, "open-ended questions are recognized to increase the richness of the data collected" (Powell, 2003).

According to many researchers (Mitchell, 1991; Chan et al. 2001) the questionnaire should be concise and "kept short", "as business people are time-pressured and unlikely to devote much time to questionnaire. Following the suggestions by Lee and King (2008), the first-round questionnaire consisted of statements based on a detailed literature review, while the feedback from this first round was used (in the form of statements) in the second round. As each round was completed, the opinions of the group moved progressively towards consensus.

In the beginning, a six-page questionna ire was developed to collect initial information and expertise's first impressions about the topic, followed by a second round two-page questionnaire. The questionnaire in this phase tackled issues such as: freight volume growth forecasts, a ppropriateness of existing polic y transport plans, susta ina bility concems and implementation along with current logistics practices. An overview of the topics can be also seen in table 4.

The second round was more specific and precise, dealing with six major issues as those appeared from the first round. Administration of the questionnaires followed the "ranking-type" Delphi studies, as Okoli and Pawlowski (2004) outlined. Questionnaire 
administration was done by mail accounts and personally and, in cases of low response rates phone calls were used or reminder letters were sent.

\section{Findings}

\subsection{Round 1: List of issues in forecasted growing volumes of freight transport}

This round was based on the ma in research objectives of the paper. Respondents were asked to answer 16 questions, and their opinions are presented in a summarized way in Table 4.

Table 4: Collected items in the $1^{\text {st }}$ round Delphi

\begin{tabular}{|c|l|c|c|c|c|}
\hline $\begin{array}{c}\text { Question } \\
\text { No. }\end{array}$ & Desc niption & $\begin{array}{c}\text { "Yes" } \\
\text { Answers }\end{array}$ & $\begin{array}{c}\text { "No" } \\
\text { Answers }\end{array}$ & $\begin{array}{c}\text { Other } \\
\text { Comments }\end{array}$ & $\begin{array}{c}\text { Total } \\
(17)\end{array}$ \\
\hline 1 & Freight traffic collapse & 10 & 0 & 7 & 17 \\
\hline 2 & Transportation modes & 17 & 0 & 0 & 17 \\
\hline 3 & $\begin{array}{l}\text { Improvement in logistics } \\
\text { practices }\end{array}$ & 9 & 5 & 2 & 16 \\
\hline 4 & $\begin{array}{l}\text { Decision- making with the } \\
\text { Master Plan }\end{array}$ & 9 & 3 & 4 & 16 \\
\hline 5 & $\begin{array}{l}\text { Timing implementation of } \\
\text { freight traffic mea sures }\end{array}$ & 1 & 10 & 6 & 17 \\
\hline 6 & $\begin{array}{l}\text { Sustainable and } \\
\text { environmental responsibility }\end{array}$ & 7 & 6 & 4 & 17 \\
\hline 7 & Logistic sproviders demands & 3 & 7 & 6 & 16 \\
\hline 8 & $\begin{array}{l}\text { Main points of sustainable } \\
\text { and environmental } \\
\text { compatibility }\end{array}$ & 8 & 9 & 0 & 17 \\
\hline 9 & $\begin{array}{l}\text { Improvement of existing } \\
\text { traffic concepts }\end{array}$ & 6 & 6 & 3 & 15 \\
\hline 10 & Altemative energy sourc es & 2 & 12 & 3 & 17 \\
\hline 11 & $\begin{array}{l}\text { Stock-keeping in supply } \\
\text { chains }\end{array}$ & 4 & 9 & 3 & 16 \\
\hline 12 & $\begin{array}{l}\text { Political and/or } \\
\text { economical task }\end{array}$ & 17 & 0 & 0 & 17 \\
\hline 13 & Responsible authorities & 11 & 6 & 0 & 17 \\
\hline 14 & $\begin{array}{l}\text { Master Plan further } \\
\text { development }\end{array}$ & 7 & 10 & 0 & 17 \\
\hline 15 & $\begin{array}{l}\text { Improved freight traffic } \\
\text { measures }\end{array}$ & 3 & 14 & 0 & 17 \\
\hline 16 & EU sustainable development & 0 & 0 & 17 & 17 \\
\hline & & & & \\
\hline
\end{tabular}

The most frequently debated issue by the panellists was the expected growth in freight transport and the role of each transportation mode in this process. Regarding improvement in logistics practices, (e.g. use of technology, better organisation of loaded transports or more effic ient operations), the opinions varied a mong respondents. Simila rly, lower consensus was achieved in the case of susta inable and environmental a wa reness in developing sustainable projects, although altemative energy sources, a voidance of large stocks and just-in-time deliveries were clearly taken into consideration when approaching this subject. Should these solutions be then regarded as a policy task or as a business one? Question to which panellists answered in consensus that it is definitely a business related task with the European Union being the responsible authority to solve the problems. Local solutions, as one of the experts mentioned, were here no more up-to-date. The next stage 
involved the discussion, interrelation, and possible further grouping of these items. Based on that, three important issues made the headlines of the second round Delphi.

1. Railways - the most susta inable means of transportation.

2. Identify the impact of the Master Plan for Freight Transport and Logistic s additional measures in the region.

3. Susta inable and ecological development of traffic polic ies within the EU.

\subsection{Round 2: In-depth analysis of the main items}

The three topics identified above were further discussed in the second round questionnaire and experts were asked to respond to six questions. Issues like the use of railroads - as an appropriate mode to deal with the growing freight volumes, supplementary measures to improve logistics processes and traffic flow, more financing and concept improvement, sustainability and environmental compatibility, responsible political board and intemodal transportation along with a reduction in energy consumption, had been tackled in the second round Delphi study. The panellists' "yes" or "no" answers were then collected and also presented in Table 6.

With reference to the first two issues findings suggest that railroads could and would solve the traffic growth as a result of globalisation and an increasing division of labour, because passenger and freight transport are closely interrelated. Both people and goods use the same infrastructure, thus railways could shape the future of freight transport and contribute to a better quality of life and protect the environment. At the same time, the further measures of the Freight Transport and Logistics Master Plan aim to make Germany even more attractive as a centre for logistics within the EU, by establishing a permanent freight transport and logistic s network.

The third issue refers to the fact that tomorrow's transport should be quiet, clean, safe, efficient and environmental friendly. Nevertheless, for a sustainable and ecological development of traffic within the EU, energy consumption reduction and intemodal transportation a re not enough to meet its $20 \%$ CO 2 reduction goal by 2020 , as one of the experts mentioned. Findings a re below disc ussed in detail according to these three main topics.

Table 5: Evaluated items in the $2^{\text {nd }}$ round Delphi

\begin{tabular}{|c|l|c|c|c|}
\hline $\begin{array}{c}\text { Question } \\
\text { No. }\end{array}$ & Desc ription & $\begin{array}{c}\text { “YES" } \\
\text { Answers }\end{array}$ & $\begin{array}{c}\text { “No" } \\
\text { Answers }\end{array}$ & Total (17) \\
\hline 1 & Railways-the most appropriate means of transportation & 16 & 1 & 17 \\
\hline 2 & Additional mea sures with the Master Plan & 17 & 0 & 17 \\
\hline 3 & Master Plan- more financing and concept improvement & 10 & 7 & 17 \\
\hline 4 & Sustainable and social responsibility & 13 & 4 & 17 \\
\hline 5 & Responsible politic al board in sustainable traffic policies & 10 & 7 & 17 \\
\hline 6 & $\begin{array}{l}\text { Energy consumption and intemodal transportation- } \\
\text { answers to a EU susta inable traffic development }\end{array}$ & 16 & 1 & 17 \\
\hline
\end{tabular}




\section{Railways - the most sustainable means of transportation}

On this topic the vast majority of experts reached a consensus. In both rounds 1 and 2 , all participants clearly regarded railways as the most appropriate and the most sustainable transport mode that could solve the forecasted growing freight traffic in the next 10 years. The respondents also recognized that waterways, namely ports, and the choice of shippers for freight transport, called for infrastructure capacity and "handling of consignments" (Hesse, 2006); unfortunately still limited (e.g. the Port of Hamburg, apparently unable to cope with expected increase in the volume of goods), as the General Director of the European Railways Industries said: "the transport volume going through seaports would continue to grow in the years to come and existing rail transport capacity is already unable to meet the demand. As a consequence, there is a strong need for additional investment in ITS (Intelligent Transport Systems) such as a) the latest signalling systems, considered being the most efficient means to enhance capacity and b) where a) is not enough, additional tracks to increase rail network ca pacity".

At the same time, another expert (from the University), added that the handling of goods in ports was often used as "buffer" and the handling time lasted on average 4 days. The expert from the German Railway Engineers Association (VDEI) suggested that also the suppliers diminished step by step their stock-keeping in the transportation chain and started to develop together with their customers log istics opera tions at optimal cost. Last but not least, the Project Manager from DB Netz AG, rounded up the image of growing volumes of goods and provided a more detailed overview upon the future of the trans-European freight traffic flows. Thus, freight should be caried out by rail by day and by night, under the condition that there were "quiet" trains and "quiet" tracks, where faster trains (speed till $160 \mathrm{Km} / \mathrm{h}$ ) could be employed. Moreover, containers should be loaded directly on rail wagons 7 days/nights in the week, expansion and reconstruction of the handling capacity in ports, expansion of the loading tracks in ports up to $750 \mathrm{~m}$, older loading devices should be tom off and the rail infrastructure should be strengthened and /or expanded in the hinterland by a partial increase of the load per axle to 25 tonnes on certain North-South railway routes. Further proposed solutions by this expert were: improvement of the signalling on the old rail sections for a continuous and energy-saving hamonised running speed especially for freight trains, as well as short-term new railway tracks construction (completion 2020) only for freight trains.

\section{Identifying the impact of Master Plan's additional measures in the region}

This topic looked into the weaknesses and strengths of freight transport and logistics practices in the Northem region of Germany. The Master Plan's initial measures focused on developing existing rail infrastructure and routes, avoiding unnecessary means of transportation, improving work conditions for people in this sector and implementation of more sustainable and environmental-friendly measures. Most experts agreed in Round 1 
that financial and transportation aspects of this Master Plan were correct but incomplete, and therefore in Round 2 they pointed out the need for additional measures that could improve logistics processes and traffic flow in the region. Nevertheless, the economic aspect was again emphasized by all panellists and additional measures, such as: more railway tracks and Intelligent Transport Systems (ITS) like the latest signalling systems were mentioned as effic ient means to enhance rail network capacity.

\section{Susta inable and ecologic al development of traffic polic ies within the EU}

All experts agreed upon the fact that susta inability and environmental compatibility were fundamental aspects in planning and organizing transport and logistics- related operations. Interestingly, one of the experts (General Manager of the European Railways Industries) argued that in reality, these two concepts were not taken into consideration when planning infrastructure. More specifically, he mentioned that "where new transport infrastructure is planned, the environmental compatibility has to be proven; and the question of sustainability however, has not been asked. Moreover, as long as extemal costs are not considered, there is also no scheme to compare the overall benefits of investment in different infrastructures under the light of sustainability". With reference to traffic policies it was clearly mentioned by almost all respondents that there was a need for EU to draw the rules to allow for more ecological development within the EU. Regarding energy consumption and intermodal transportation, all experts reached a consensus regarding these two issues, although the General Director of the European Railways Industries mentioned before that according to the European Environment Agency report entitled "Climate for a Transport Change", energy consumption reduction (i.e. technology) would not do the job.

\section{Discussion}

The results of this Delphi study ind ic ate that the most important factors of improving the existing infrastructure network in North Gemany are the implementation of improved logistics practices, and freight traffic concepts, the development of Master Plan Projects as well as expansion of the existing rail network capacity and finally a deeper involvement of the policy and business a uthorities.

Most experts see better logistics practices as a possible solution to solve traffic congestion, as improved techniques could reduce the number of transports camied out on long routes, although according to some experts the high number of transports had to be camied out by the existing ways: road, water or rail. Regarding improved traffic concepts and development of Master Plan Projects, respondents' answers fluctuated between an efficient controlling of the targets of the existing concepts and any alreadystarted concept to be re -verified and improved. Furthermore, the Master Plan should not 
be treated independently from all other traffic concepts within the EU. Moreover, within the master plan project for improving links between the Geman ports and their hinterlands, "activity is currently concentrating on those that tranship the largest volume of freight, which also happen to be the fastest-growing ones" (Belter et al., 2008).

Policy measures and technological developments, expansion of the railway infrastructure along the European Rail Freight Comidors, insta llation of integrative signalling techniques (i.e. ERTMS), as well as a prioritisation of freight trains on certain routes, are important fac tors that a ffect a ny log istic al decision-making of organiza tions in susta ina ble supply chains (Goldsby and Stank, 2000; Voordijk, 1999). Equally important are the strategic planning issues like teminal design, infrastructure network configuration and freight consolidation (C a ris et al., 2008; Kohn and Brodin, 2008; Bontekoning and Priemus, 2004). However, the findings of other researchers are not so positive, since most innovations in rail freight and terminal markets have not been adopted because of limited improvement in product characteristics, scarce financing and a little influence on the total transportation solutions. Moreover, as Kohn and Brodin (2008) found out, in general the field of strategic changes in logistics systems was poorly covered in specialized literature and called for further research attention, and not only from an environmental point of view.

\section{Conclusions}

The aim of this paper was to provide an in-depth analysis of the transport sector in North Germany in an effort to identify, if any, the possibilities of collapse as a result of the continuous increase in the demand of freight traffic. Findings indicated that railways could represent the solution to the forecasted growing freight volumes in the next years, not only in Germany but also in the whole European transport sector. The most important views of the experts were the additional measures within the Master Plan, increasing financing, energy consumption reduction, intermodal transportation, politics implication, and sustainable and environmental-friendly logistics concepts. At the same time, the panellists concluded that each and every measure taken with Master Plans was important if the country has the will to overcome congestion in traffic.

The paper has shown that in spite of continuous efforts undertaken by the politics and the economy, the existing logistics and freight traffic concepts in North Germany are not sufficient. Financing is too scarce; traffic concepts take issues like sustainability, environment protection and working conditions into little consideration. Altemative possibilities that could be generated from new and modem logistics concepts rema in to a large extent unconsidered. In that respect, future research should be conducted using the same or other more specialized methodologies, "more extended questionna ires, more expert panels (e.g. two)" (Manoliadis et al. 2006). An altemative research method for 
identifying possible solutions to the forecasted increase in freight traffic demand could be the use of case studies caried out by major traffic operators within their companies. Limitations of the research refer to the fact that due to the exploratory character of this study, the sample is not representative for Geman transportation sector, but the results of each round of Delphi indicated an interesting insight into experts "conceptualizations" (Wright, 2007) of what really represented a necessary analysis of the existing worying situation in the freight transport.

\section{References}

Belter, B., Bohrer, W. and Kunefke, F. (2008) Master plans for the rail infrastructure for the five largest Geman ports. Ra ilways Technical Review, 4, p. 178-190 (in Geman).

Bergqvist, R. (2008) Evaluating road-rail intemodal tra nsport servic es-a heuristic approach. Intemationa I J oumal of Log istic s: Research and Applic ations, 11(3), p.179-199.

BMVBS, (2008). Federal Ministry of Transport, Building and Urban Affairs. http://www.bmvbs.de/cae/servlet/contentblob/34150/publicationFile/3179/freighttransport-and-logistics-masterplan.pdf [Accessed 8th April 2011].

Bolis, S. and Maggi, R. (2003) Logistics Strategy and Transport Service Choices: An Adaptive Stated Preference Experiment. Growth and Change, 34(4), pp. 490-504.

Bontekoning, Y. and Priemus, H. (2004) Breakthrough Innovations in Intermodal Freight Transport. Transportation Planning and Technology, 27(5), pp. 335-345.

Bulcsu, S. (2011) The process of liberalising the rail freight transport markets in the EU: The case of Hungary, Intemational J oumal of Logistics Systems and Management, 9(1) pp. $89-107$.

Caimi, G., Burkolter D., Hemmann, T., Chudak, F. and Laumanns, M. (2009) Design of a Railway Scheduling Model for Dense Services. Networks and Spatial Economics, 9(1), pp. 25-46.

Caris, A., Macharis, C. and Janssens, G. (2008) Planning Problems in Intermodal Freight Transport: Accomplishments and Prospects. Transportation Planning and Technology, 31(3), pp. 277-302. 
CBRE, (2012) Logistics Gemany Annual Report, Available at http://www.cbre.eu/portal/pls/portal/res_rep.show_report? report id=1892 [Accessed 18th August 2012].

Chan, A., Yung, E., Lam, P., Tam, C.M. and Cheung, S.O. (2001) Application of Delphi method in selection of procurement systems for construction projects. Construction Management and Economics, 19, pp. 699-718.

CEC (2006) Keep Europe moving -Susta inable mobility for our continent Mid-term review of the European Commission's 2001 Transport White Paper. Brussels, pp. 1-29.

DB Konzem (2008) European Railways with a new climate Target. Berlin, Deutsche Bahn AG. Ava ilable at: http://www.db.de/site/bahn/de/untemehmen/verantwortung/umwelt/klimaschutz [Accessed 16th J uly 2008].

DB Konzem (2010a) Fast and efficient solutions - all over the world. Deutsche Bahn AG. Available at:

http://www.deutschebahn.com/site/bahn/de/geschaefte/logistik [Accessed 31st March 2010]. DB Konzem (2010b) Our environment and climate protection have a high significance [online]. Deutsche Bahn AG. Available at: http://www.deutschebahn.com/site/nachahaltigkeitsbericht -2009 [Accessed 31st March 2010].

DB Konzem (2012). German Freight Transport Market [online]. Deutsche Bahn AG. Available at: http://www.deutschebahn.com/site/business/markets-2011 [Accessed 20th March 2013]. DB Schenker (2010) Logistic s-Know-how from Analyse to Realisation [online]. Deutsche Bahn AG. Available at: http://www.dbschenker.com/site/logistics/dbschenker/com/de/produkte_services [Accessed 31st March 2010].

DB Schenker (2010) Environmental facts from DB Schenker Rail [online]. Deutsche Bahn AG. Available at: http://www.dbschenker.com/site/logistics/dbschenker/com/de/umwelt/daten_fakten [Accessed 31st March 2010]. 
European Railway Review, (2012) Archives for Gemany, Available at: http://www.europeanrailwayreview.com/tag/gemany/ [Accessed 28th March 2013].

Eurostat (2011) Freight transport statistics, Available at: http://epp.eurostat.ec.europa.eu/statistic s_explained/index.php/Freight_transport_stati stics, [Accessed 16th August 2012].

Ghijsen, P., Semeijn, J. and Van Der Linden, H. (2007) Rail Freight in Europe: Different Perspectives on Achieving Higher Service Levels. Transportation J oumal, 46(4), pp. 4257.

Goldsby, T. and Stank, T. (2000) World Class Logistics Performance and Environmentally Responsible Logistics Practic es. J oumal of Business Log istic s, 21(2), pp. 187-208.

Hesse, M. (2004) Logistics and Freight Transport Policy in Urban Areas: A Case Study of Berlin-Brandenburg/Germany. European Planning Studies, 12(7), pp. 1035-1052.

Hesse, M. (2006) Global Chain, Local Pain: Regional Implications of Global Distribution Networks in the German North Range. Growth and Change, 37(4), pp. 570-596.

Kohn, C. and Huge-Brodin, M. (2008) Centralised distribution systems and the environment: how increased transport work can decrease the environmental impact of logistic s. Intemational J oumal of Logistic s: Research and Applications, 11 (3), pp. 229-245.

Laisi, M. (2011) Bamiers to entry in railway freight market: building knowledge through Swedish and Polish operators' experiences, Intemational J oumal of Logistics Systems and Management, 8 (3), pp. $350-362$.

Lee, Cheng-Fei and King, B.E. (2008) Using the Delphi Method to Assess the Potential of Ta iwan's Hot Springs Tourism Sector. Intemational J oumal of Tourism Research, 10, pp. 341-352.

Lindner, T. and Pachl, J. (2010). Recommendations for Enhancing UIC Code 406 Method to Evaluate Railroad Infrastructure Capacity, Available at: http://www.digibib.tu$\underline{\text { bs.de } / ? \text { docid }=00032112}$

Link, H. (2008) Acceptability of the Geman Charging Scheme for Heavy Goods Vehic le: Empinc al Evidence from a Freight Company Survey. Transport Reviews, 28(2), pp. 141158. 
Lummus, R.R., Vokurka, R.J . and Duclos, L.K. (2005) Delphi Study on supply cha in flexibility. Intemational J oumal of Production Research, 43(13), p. 2687-2708.

Manoliadis, O., Tsolas, I. and Nakou, A. (2006) Susta inable construction and drivers of change in Greece: a Delphi study. Construction Management and Economics, 24, pp. 113-120.

McKinnon, A. and Forster, M. (2000) Full Report of the Delphi 2005 Survey- European Logistical and Supply Cha in Trends: 1999-2005. Edinburgh-Logistics Research Centre, Heriot-Watt University, pp. 1-19.

Mitchell, V.W. (1991) The Delphi Technique: an Exposition and Application. Technology Analysis \&Strategic Management, 3(4), pp. 333-357.

Okoli, C. and Pawlowski, S. (2004) The Delphi method as a research tool: an example, design considerations and a pplic ations. Information \& Management, 42, pp. 15-29.

Powell, C. (2003) The Delphi tec hnique: myths and realities. J oumal of Advanced Nursing, 41(4), pp. 376-382.

Progtrans, (2009). Statistic al coverage and economic analysis of the logistic sector in the EU (SEALS), Prepared for the European Commission, DG Energy and Transport Available at: http://ec.europa.eu/transport/strategies/studies/doc/2008_12 logistic s.pdf [Acc essed 18th August 2012]

Pro-rail Alliance (2008). Press release No.12/2008. Available at: http://www.allianz-proschiene.de/eng/press/press-releases/2008/2008-54/ [Accessed 9th April 2012] (in German).

Seuring, S. and Müller, M. (2007) Core Issues in Susta ina ble Supply Cha in Management- a Delphi Study. Business Strategy and the Environment, 17(8) pp. 1-13.

Slack, B. and Vogt, A. (2007). Challenges confronting new traction providers of rail freight in Germany, Transport Polic y, 14, pp. 399-409.

VDV (2010a) Association of Geman Transport Undertakings, Press release (Number 2). Available at: http://www.vdv.de/medienservice [Accessed 9th April 2012] 
VDV (2010b) Association of German Transport Undertakings, VDV-Yearly Report 2007/08. Available at: http://www.vdv.de/module/layout_upload/jb_07_08.pdf [Accessed 8th April 2012].

VDV (2010c) Association of Geman Transport Undertakings VDV-Yearly Report 2008/09. Available at: http://www.vdv.de/module/layout upload/jb_08 09.pdf [Accessed 8th April 2012].

Voordijk, H. (1999) Logistic al Restructuring of Supply Chains of Building Materials and Road Freight Traffic Growth. Intemational J oumal of Logistics: Research and Applications, 2(3), pp. 285-303.

Wagener, N. (2008) The German logistics experience with freight villages-is it appropriate for Ukraine? Available at: http://www.wagener-herbst.com. [Accessed 20th March 2013].

Wright, T. (2007) Developing research priorities with a cohort of higher education for susta ina bility experts. Intemational J oumal of Susta ina bility in Higher Education, 8(1), pp. 34-43. 


\section{Short Biographical note:}

\section{Gabriela Ztz}

She holds an Executive MBA degree with Menit in Logistics from the University of Sheffield, UK and she was a team leader within the Logistics Department of BLP Wiebe Romania Company for 3 years in Romania, while she also worked as an Assistant Logistic $s$ Manager in Greece, within the "Railway Track New Construction Project Athens-Kiato" from the National G reek Ra ilway Company. Also, for 3 years (2001-2004) she worked as an Assistant Project Manager within the German-Romanian J oint-Venture, having as a ma in project Railway Track Renewal and partially, Construction in Romania. Her current interests include: logistics service providers, rail logistics, passenger and freight traffic particularly in Northem Germany.

Dr Aristides Ma topoulos

$\mathrm{He}$ is a Lecturer in Logistics and Supply Cha in Management in the Engineering Systems \& Mana gement Group, School of Eng ineering \& Applied Science at Aston University. Prior to that, he was an Adjunct Lecturer for 4 years in the University of Macedonia and in the Aristotle University of Thessa loniki. In 2010, he was awarded a one year post-doc grant on "Innovation in the Food Chain" from the Greek State Scholarships Foundation. Also, for 3 years (2006-2009) he worked as a researcher in the FP6 European Project "e-Trust", which dealt with the exploration and analysis of the trust factors affecting companies in the food $c$ ha in in their transition from tra ditional to electronic B2B relationships. His c urrent research interests include: Resource Efficient Supply Chains, Humanitarian Supply Cha ins and AgriFood Logistics. 